УДК 621.372

ПОНОМАРЕНКО В. И. ${ }^{1}$, ПОПОВ В. В. ${ }^{1}$, КУИН Ф. ${ }^{2}$

\title{
АНАЛОГ ЧЕТВЕРТЬВОЛНОВОГО РАДИОПОГЛОТИТЕЛЯ НА ОСНОВЕ МИКРОПРОВОДОВ
}

\author{
${ }^{1}$ Таврический национальньій университет им. В. И. Вернадского, \\ Украина, Симферополь, 95007, пр-т Вернадского, 4 \\ ${ }^{2}$ Объединенный центр инноваџий и науки, Бристольский университет, \\ Великобритания, Бристоль, Queen's Building, University Walk, Bristol BS8 1TR
}

\begin{abstract}
Аннотация. Рассмотрена периодическая структура из микропроводов, расположенных над металлическим зеркалом. Получены условия согласования такой структуры со свободным пространством. Показано, что при достаточно малом периоде структуры и выполнении условий согласования частотная зависимость коэффициента отражения близка к таковой для четвертьволнового слоя. Возможность варьирования в широких пределах импеданса проводов и геометрии их расположения в радиопоглотителе позволяет влиять на его частотную характеристику
\end{abstract}

Ключевые слова: радиопоглощающая структура; задача рассеяния; микропровод

\section{ВВЕДЕНИЕ}

Поглотители электромагнитных волн (ПЭВ) широко применяются в технике сверхвысоких частот для оборудования безэховых камер и других целей [1]. Развитие ПЭВ шло как на базе новых типов структур, таких как многослойные, шиповидные, шахтные и т.д., так и на основе применения новых материалов - диэлектрических, магнитных, композиционных [2-4].

Одним из таких перспективных материалов являются аморфные микропровода из магнитных и немагнитных сплавов, основная электромагнитная характеристика которых импеданс (комплексное погонное сопротивление) - может варьироваться в широких пределах путем изменения состава и толщины проводов [5-7]. Такое варьирование позволяет влиять на поглощающие свойства структуры, содержащей микропровода, с целью обеспече- ния оптимальной частотной зависимости коэффициента отражения.

Целью работы является обоснование возможности применения микропроводов в ПЭВ на примере структуры, являющейся аналогом четвертьволнового поглотителя (ЧП), представляющего собой проводящую пленку с поверхностным сопротивлением $Z_{0}=120 \pi \approx 377$ Ом, расположенную на расстоянии четверти длины волны от экранируемого металлического зеркала [2].

Исследуемая структура (ИС), изображенная на рис. 1, состоит из системы тонких проводов радиуса $\delta$ с импедансом $\widetilde{Z}$ параллельных оси $Y$, расположенных с периодом $a$ по оси $X$ на расстоянии $l$ от идеально проводящей плоскости. Поляризованная вдоль оси $Y$ электромагнитная волна длины $\lambda>a$ распространяется вдоль оси $Z$ из области $z=-\infty$. 